\title{
Rancang Bangun Mesin Penghancur Kacang Tanah Menggunakan Motor Induksi
}

\author{
Rizal Oponu ${ }^{1)}$, Siradjuddin Haluti' ${ }^{2}$, Burhan Liputo ${ }^{3)}$ \\ 1,2,3) Program Studi Mesin dan Peralatan Pertanian, Politeknik Gorontalo \\ Jl. Muchlis Rahim, Desa Ponggulo Barat, Kec. Botupingge, Kab. Bone Bolango, Gorontalo, Indonesia \\ e-mail: rizaloponu47@gmail.com
}

\begin{abstract}
ABSTRAK
Kacang tanah merupakan salah satu tanaman yang memiliki banyak manfaat karena kandungan gizinya, seperti protein dan lemak. Diantara pemanfaatannya adalah sebagai bahan baku pembuatan kue kurma. Kue kurma adalah salah satu jenis kue yang bagian luarnya dilumuri/ditaburi dengan kacang tanah yang sudah dihancurkan. Proses penghancuran kacang tanah selama ini menggunakan alat tradisional berupa kayu dan botol. Penggunaan alat tradisional ini memiliki kelemahan karena memerlukan tenaga dan waktu yang cukup lama. Oleh karena itu diperlukan alat atau mesin yang dapat membantu masyarakat dalam proses penghancuran kacang tanah untuk pembuatan kue kurma. Pada penelitian ini dirancang suatu mesin penghancur kacang tanah dengan menggunakan motor induksi 1/4 HP. Penelitian ini bertujuan selain merancang mesin juga untuk mengetahui kinerja mesin penghancur kacang tanah. Mesin penghancur kacang tanah dibuat di Laboratorium Mesin Umum Politeknik Gorontalo. Mesin ini dibuat dari bahan stainless steel dengan sistem transmisi menggunakan pulley 4 inchi. Mesin dirancang untuk menghancurkan kacang tanah sesuai ukuran yang diinginkan dengan kapasitas 500 gr. Hasil penelitian menunjukkan bahwa proses penghancuran kacang tanah lebih cepat dibandingkan menggunakan alat tradisional. Proses penghancuran menggunakan mesin hanya memakan waktu antara 27-29 detik untuk 500 gr kacang tanah. Sedangkan penghancuran menggunakan alat tradisional memerlukan waktu 6-10 menit untuk berat kacang tanah yang sama. Dengan demikian mesin ini dapat meghancurkan kacang tanah 12 kali lebih banyak dibandingkan alat tradisional. Kinerja mesin ini mampu menghancurkan kacang tanah sekitar 64,3 kg/jam.
\end{abstract}

Kata Kunci: mesin penghancur, kacang tanah, kue kurma

\begin{abstract}
Peanut is a plant that has many benefits because of its nutritional content, such as protein and fat. Among its uses is as a raw material for making date cakes. Dates cake is a type of cake that is covered with crushed peanuts on the outside. The process of crushing peanuts has been using traditional tools such as wood and bottles. The use of this traditional tool has a weakness because it requires a lot of energy and time. Therefore, a tool or machine is needed that can help the community in the process of crushing peanuts for making date cakes. In this study, a peanut crusher machine was designed using a $1 / 4$ HP induction motor. This study aims in addition to designing the machine as well as to determine the performance of the peanut crusher machine. Peanut crusher machine is made at the General Machinery Laboratory of Politeknik Gorontalo. This machine is made of stainless steel with a transmission system using a 4 inch pulley. The machine is designed to crush peanuts according to the desired size with a capacity of $500 \mathrm{gr}$. The results showed that the process of crushing peanuts was faster than using traditional tools. The crushing process using a machine only takes between 27-29 seconds for 500 grams of peanuts. While crushing using traditional tools takes 6-10 minutes for the same weight of peanuts. Thus this machine can crush 12 times more peanuts than traditional tools. The performance of this machine is capable of crushing peanuts around $64.3 \mathrm{~kg} / \mathrm{hour}$.
\end{abstract}

Keywords: crushing machine, peanuts, date cake 


\section{PENDAHULUAN}

Provinsi Gorontalo merupakan salah satu wilayah yang memiliki banyak tanaman pertanian, salah satunya tanaman kacang tanah. Kacang tanah (arachis hypogaeal.L) merupakan tanaman leguminosa yang cukup penting di Indonesia. Tanaman ini merupakan tanaman yang paling banyak setelah padi, jagung, dan kacang keledai. Kacang tanah biasanya ditanam sebagai tanaman tumpang sari. Namun banyak petani kurang memperhatikan untuk menanam kacang tanah, karena hasil yang dicapai masih sangat rendah perhektarnya.

Kacang tanah memiliki beberapa kelebihan jika dibandingkan dengan tanaman kacang-kacangan yang lain yaitu: lebih tahan terhadap kekeringan, hama dan penyakit relatif sedikit, panen relatif cepat pada umur 55 sampai 60 hari, cara tanam dan pengelolaan dilapanganya serta perlakuan pasca panen relatif mudah, kegagalan panen total relatif kecil, harga jual tinggi dan stabil (Surbakti, 2011).

Di beberapa daerah di Indonesia, kacang tanah merupakan tanaman pangan yang mendapat prioritas untuk dikembangkan dan ditingkatkan produksinya setelah padi dan kedelai. Hal ini didorong dengan semakin meningkatnya kebutuhan terhadap kacang tanah sebagai bahan pangan maupun bahan baku industri. Penggunaan kacang tanah sangat beragam mulai dari industri rumah tangga secara tradisional sampai ke industri modern (Mashudi, 2007).

Pada umumnya kacang tanah digunakan sebagai makanan ringan atau tambahan pada kue. Masyarakat Gorontalo sering memanfaatkan kacang tanah untuk tambahan (toping) pada kue kurma (Gambar 1). Kue kurma merupakan kue yang banyak dijumpai di masyarakat, terutama Gorontalo. Kacang tanah yang digunakan adalah kacang tanah yang telah digoreng tanpa minyak (sangrai) sehingga memudahkan dalam proses penghancuran (tidak lengket). Meski pemanfaatan kacang tanah sebagai tambahan kue kurma sudah dilakukan dengan sangat baik, namun hingga saat ini sebagian masyarakat di Provinsi Gorontalo memiliki kendala dalam proses penghancuran kacang tanah, dimana masyarakat masih menggunakan alat-alat tradisional.

Alat-alat yang biasa digunakan masyarakat untuk proses penghancuran kacang adalah kayu atau botol. Penggunaan kayu dan botol sebagai penghancur kacang tanah tentunya memiliki kekurangan, diantaranya adalah membutuhkan waktu dan tenaga yang cukup besar. Hal ini tentu akan mempengaruhi efektivitas dan efisiensi produksi kue kurma. Permasalahan lain adalah masyarakat lebih cepat lelah dan butiran kacang yang dihancurkan tidak seragam. Oleh karena itu, perlua adanya alat atau mesin yang dapat digunakan untuk membantu dalam proses penghancuran kacang tanah. Harapannya adalah dapat meningkatkan produktivitas sebagai mengefisienkan waktu dan tenaga yang digunakan.

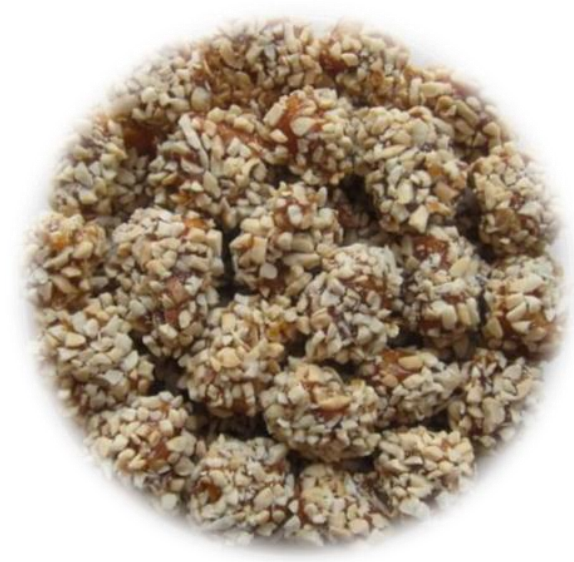

Gambar 1. Kue Kurma (https://resepkoki.co/resepkue-kacang-kurma/)

\section{METODE PENELITIAN}

\section{Desaian dan Perancangan}

Mesin penghancur kacang tanah didesain dengan dilengkapi beberapa komponen seperti hopper, stopper (pengunci), adjuster (pengatur pecahan kacang), hopper bawah (output), penutup, kopling, gear box, pulley, dan dinamo (Gambar 2).

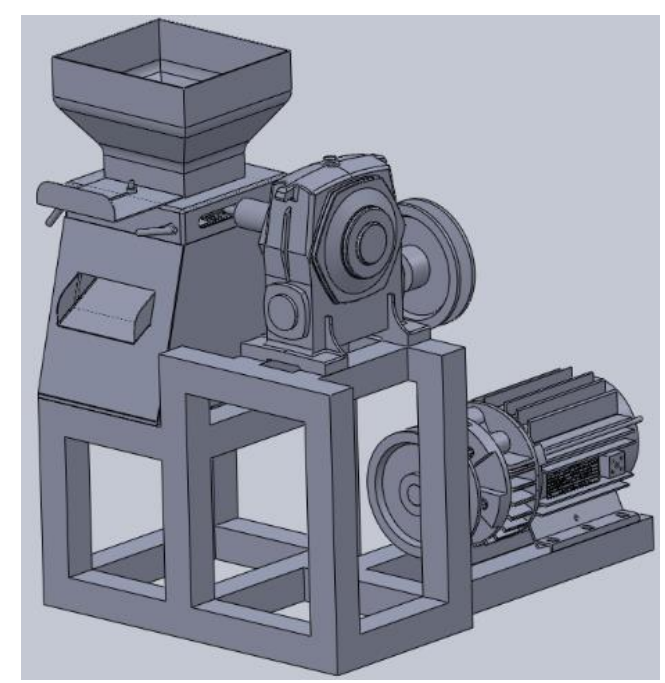

Gambar 2. Desain Mesing Penghancur Kacang Tanah 


\section{Pembuatan dan Fabrikasi}

Mesin penghancur kacang tanah dibuat di Laboratorium Mesin Prodi Mesin dan Peralatan Pertanian. Pembuatan dimulai dari tahap perancangan fungsional hingga struktural (Gambar 3). Prinsip kerja mesin ini adalah menghancurkan kacang tanah dengan dua buah poros bergigi yang berputar sehingga pecahan kacang tidak hanya terbelah menjadi dua bagian, tetapi akan hancur sesuai dengan dimensi yang diinginkan pada pembuatan kue kurma.

\section{Prosedur Pengujian}

Pengujian mesin dilakukan dengan tahapantahapan berikut:

1. Menyiapkan kacang tanah yang akan dihancurkan sebanyak 500 gr.

2. Kacang tanah dimasukkan ke dalam hopper input.

3. Proses penggilingan dan penghancuran dilakukan dengan menekan tombol on untuk menyalakan dinamo.

4. Mengukur lamanya waktu penghancuran

5. Mengukur dimensi kacang tanah hasil penghancuran.

6. Pengujian dilakukan sebanyak tiga kali

\section{HASIL DAN PEMBAHASAN}

\section{Perancangan Mesin}

Perancangan mesin pemecah biji kacang tanah ini dibuat dari bahan stainles steel, dan rangka untuk dudukan dinamo dan gear box terbuat dari besi siku 3x3 mm (Gambar 3). Mesin ini memiliki beberapa komponen yang memiliki fungsi masing-masing, diantaranya adalah:

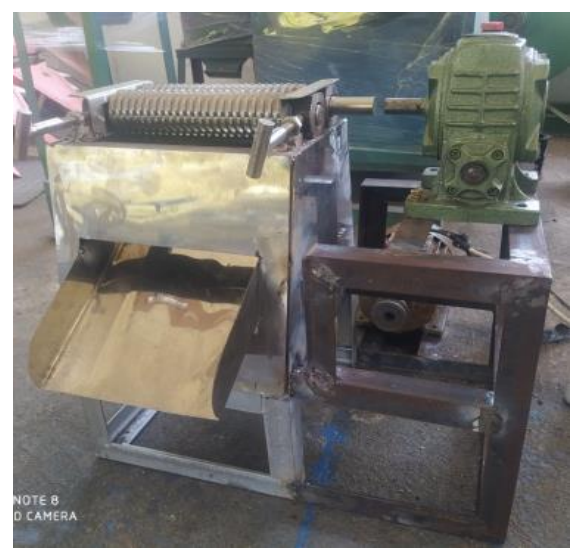

Gambar 3. Mesin Penghancur Kacang Tanah
1. Hopper atas

Hopper atas fungsinya untuk menampung biji kacang yang belum pecah atau biji kacang yang masih utuh.

2. Stoper (pengunci)

Stoper fungsinya yaitu untuk menahan biji kacang agar pada saat menumpahkan biji kacang di dalam kover atas, biji kacang tdk langsung tersentuh pada poros.

3. Adjuster (stelan pecahan kacang)

Adjuster fungsinya untuk pengaturan pecahan kacang dengan menggeser poros 2 .

4. Hopper bawah

Hopper bawah fungsinya yaitu tempat keluarnya biji kacang yang sudah pecah.

5. Plat penutup

Plat penutup yaitu plat yang terdapat pada dinding hoper bawah.

6. Kopling

Kopling fungsinya untuk menyatukan poros 2 dengan poros gear box.

7. Gear box

Gear box fungsinya yaitu untuk memperlambat putaran dinamo yang akan di teruskan ke poros pemecah biji kacang.

8. Pulley

Pulley fungsinya untuk kedudukan $v$ belt

9. Dinamo (Motor induksi)

Dinamo (motor induksi) fungsinya untuk menjalankan alat melalui $\mathrm{v}$ belt yang akan di teruskan ke gear box.

10.Rangka

Rangka fungsinya yaitu untuk kedudukan kover bawah, gir box dan untuk kedudukan dinamo (motor induksi).

\section{Hasil Pengujian}

Hasil pengujian mesin pengahncur kacang tanah dapat dilihat pada Tabel 1 .

Tabel 1. Hasil Pengujian

\begin{tabular}{ccccccc}
\hline \multirow{2}{*}{$\mathrm{N}$} & $\mathrm{W}$ & $\mathrm{t}$ & \multicolumn{3}{c}{$\emptyset(\mathrm{mm})$} \\
\cline { 4 - 7 } & $(\mathrm{gr})$ & $($ detik $)$ & 1 & 2 & 3 & Rata-rata \\
\hline 1 & 500 & 29 & 2,8 & 3 & 2 & 2,6 \\
2 & 500 & 28 & 3 & 2,5 & 1,5 & 2,3 \\
3 & 500 & 27 & 2,5 & 2,3 & 1 & 1,9 \\
\hline
\end{tabular}

Ket:

$\mathrm{N} \quad=$ jumlah pengujian

$\mathrm{W}=$ berat kacang tanah

$\mathrm{t} \quad=$ waktu pengujian

$\varnothing \quad=$ diameter kacang hasil penghancuran 
Hasil pengujian pada Tabel 1 menunjukkan bahwa putaran yang digunakan pada proses penghancuran akan berpengaruh pada dimensi kacang tanah yang dihasilkan. Pada pengujian pertama dengan kapasitas alat 500 gram memerlukan waktu 29 detik dengan hasil pecahan kacang memiliki dimensi rata-rata 2,6 mm (Gambar 4a). Pada pengujian kedua waktu yang diperlukan pada proses penghancuran adalah 28 detik, sedikit lebih cepat dibandingkan pada pengujian pertama. Kacang tanah hasil pengujian kedua memiliki dimensi rata-rata $2,3 \mathrm{~mm}$ (Gambar 4b). Pada pengujian ketiga mesin pemecah biji kacang tanah memerlukan waktu 27 detik dengan hasil pecahan halus dengan dimensi rata-rata 1,9 mm (Gambar 4c).

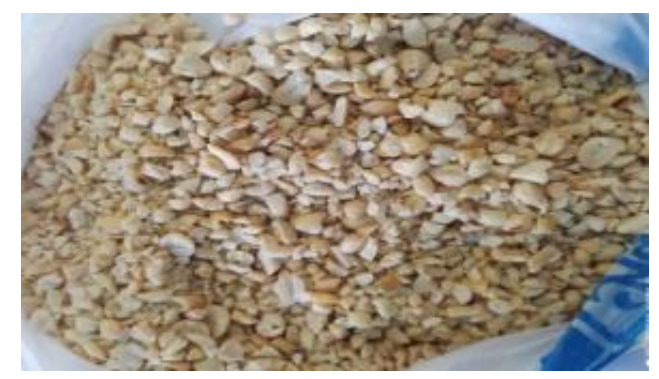

(a)

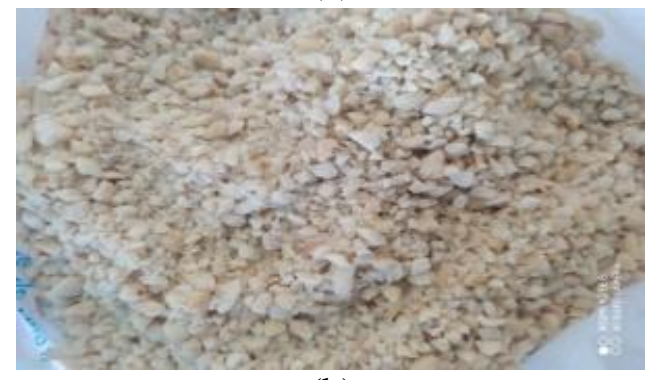

(b)

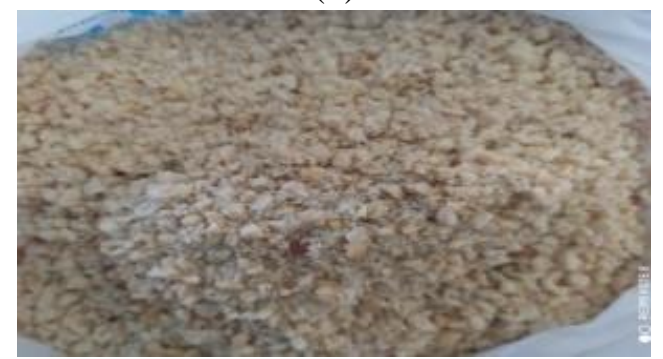

(c)

Gambar 4. Produk Kacang dengan Variasi Waktu Kerja Mesin (a) 29 detik, (b) 28 detik, dan (c) 27 detik

Produk yang dihasilkan pada mesin penghancur kacang tanah di atas lebih baik jika dibandingkan dengan alat tradisional. Hal ini dapat dilihat dari dua aspek, yaitu waktu dan ukuran kacang yang dihasilkan. Dari segi waktu, penggunaan alat tradisional (kayu dan botol) dapat memakan waktu 6-10 menit untuk berat kacang tanah yang sama. Sehingga alat ini dapat mereduksi waktu pengerjaan yang sangat besar. Dari segi ukuran kacang, penggunaan alat teradisional menghasilkan kacang yang ukurannya sangat besar (Gambar 5) sehingga memerlukan waktu yang lebih lama agar kacang dapat lebih halus.

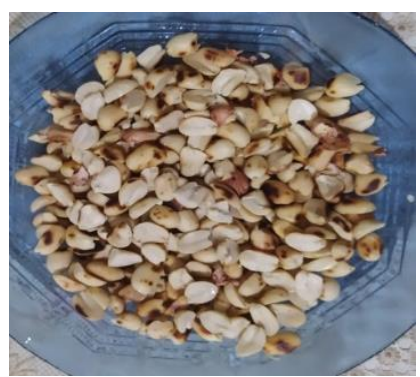

Gambar 5. Hasil Penghancuran Kacang Menggunakan Alat Tradisional

Dengan demikian, mesin penghancur kacang tanah dapat menajdi solusi bagi masyarakat pembuat kue kurma karena dapat menghemat waktu dan tenaga.

\section{KESIMPULAN}

Berdasarkan hasil penelitian disimpulkan beberapa hal berikut:

1. Mesin penghancur kacang tanah dibuat dari bahan stainless steel dengan rangka dan dudukan dinamo \& gear box terbuat dari besi siku $3 \times 3$ $\mathrm{mm}$.

2. Motor yang digunakan pada mesin penghancur tanah adalah motor induksi $1 / 4 \mathrm{HP}$ dengan putaran motor $1200 \mathrm{rpm}$.

3. Mesin ini dapat meghancurkan kacang tanah sekitar 64,3 kg/jam. Hasil ini lebih banyak jika menggunakan alat tradisional yang hanya mampu menghancurkan kacang tanah sekitar 3-5 kg/jam.

\section{DAFTAR PUSTAKA}

Hadiutomo, (2012), Mekanisasi Pertanian. Bogor: IPB Press.

Mashudi, (2017), Produktivitas Kacang Tanah Di Lahan Kering. pada Berbagai Intensitas Penyiangan. Program Studi Agroteknologi.

Murrine, E.D., (2010), Analisis Pertumbuhan Kacang Tanah dan Pergeseran. Komposisi 
Gulma pada Frekuensi Penyiangan dan Jarak Tanam yang Berbeda.

Richard., dkk., (2011), Sclerotium Rolfsii Banyak Ditemukan pada Musim Hujan, Terutama pada Tanah yang Lembab.

Simamora, (2011), Respon Pertumbuhan dan Produksi Tanaman Kacang Tanah (Arachis hypogaea $L$.)

Surbakti, (2011), Kacang Tanah.

$\mathrm{http} /$ penelitiankacangtanah.html.com

https://resepkoki.co/resep-kue-kacang-kurma/

diakses pada tanggal 10 September 2020 